\title{
Financial Resources Management for SME`S of Mongolia
}

\author{
Ganbold Solongo ${ }^{1}$ \\ ${ }^{1}$ Department of Business Administration, South China University of Technology, Guangzhou, China \\ Correspondence: Ganbold Solongo, Department of Business Administration, South China University of \\ Technology, Guangzhou, China \\ Received: April 6, 2017 \\ Accepted: April 27, $2017 \quad$ Online Published: May 18, 2017 \\ doi:10.5539/ibr.v10n6p145 \\ URL: https://doi.org/10.5539/ibr.v10n6p145
}

\begin{abstract}
This paper Financial resources management analyzes the sources of financing for the medium enterprises in Mongolia by comparing between limited liability companies and public listed companies who are actively working in trading, manufacturing and service providing companies external and internal sources of finances. The paper gives an overview of the related theories of financial sources and capital structuring and aimed to approve based on the empirical studies on the selected three different industries 14 companies (based on the empirical studies done on 14 companies within three different industries). This paper also defined an optimal capital structure for the selected industries and each company based on the scenario analysis and assumptions. This paper investigates the sources of financing for the medium enterprises in Mongolia in different ownership structures by a capital structure theories and their impact on corporate financial performances. There are several theories regarding the process of business financing in general, companies can obtain sources of finances from short term sources, debt finance, venture capital, equity finance and internal sources.
\end{abstract}

Keywords: Small \& Medium Sized Enterprises (SME), capital structure, optimal capital structure, financial performances

\section{Introduction}

\subsection{Statement of the Problem}

The primary purpose of the business is to maximize shareholder's value and in order to fulfill that each business needs sources of finance. Why and how to finance a business is one of the key concerns for business owners or business executives.

However, depending on the business enterprise's background, type of operation, financial position and business sector, business entities are available to use (single or multiple types of financial sources)in Mongolia.

This paper is only exploring medium enterprises that are actively operating at the Mongolian market in particular with trading, manufacturing and service providing industries.

Medium enterprises have difficulty to obtain finance from different sources because of tight liquidity constraints. So, most of medium enterprises lack experience and expertise to collect financial sources from short term sources, debt finance, venture capital, equity finance and internal sources. However, some enterprise's financial position, strategy and executive's knowledge and experience who are using different type of sources of finances. So, this paper is aimed to explore a different type of financial sources management by exploring internal and external sources of financial instrument.

\subsection{Purpose}

Mongolian medium enterprises face a number of difficulties and challenges including tax pressure, financial sources, financial position of buyers etc., from business communities on their firms' entire life. But one of the biggest problems is sources of finances for their main business activities and further strategic diversifications.

Most of medium-scale enterprise has limited resources on their workforce, financial, physical, and educational and knowledge. Specially, financing is the most difficult work to deal with. So, this paper 'Financial sources management' analyzes the sources of financing for the medium enterprises in Mongolia by comparing between trading, manufacturing and service providing companies external and internal sources of finances. This paper also defined an optimal capital structure for the selected industries and each company based on the scenario analysis and assumptions.

Every business enterprise has own financial strategy and its sources based on their business and ownership 
structure. However, depending on their scope of business, they are using different sources of finances from different type of financial institutions such as local banks, international banks, SME funds etc..

Medium enterprises cannot operate properly without any funding. In order to create a fund, enterprises need to use some certain sources. But depending on the enterprise background and capacity, some sources of funding are limited for them.

\subsection{Methodology}

The financial statements were obtained for selected 14 enterprises and they are categorized into three groups based on their business activities namely Manufacturing (5). Trading (5) and Service providers. From the financial statements, various financial ratios were derived. Using the financial ratios, the enterprises were ranked and categorized as well performing (WP) and non-well performing enterprises (NWP). At the same time, in order to compare a capital structuring, this paper also selected 13 companies who are publicly listed on the Mongolian Stock Exchange and calculated each industry beta that measure the volatility of the security in comparison to the TOP-20 index. Therefore, paper also calculated debt to equity ratio between industries and defined an existing capital structure that is aimed to compare between Limited Liability Company and public listed companies. Last chapter of the paper defines an optimal capital structure of the selected industries.

The paper uses carefully analyzed and chosen research methods and techniques, including the rationale behind a qualitative research approach. Additionally, the exploited data collection and analysis methods are characterized.

\subsection{Selected Enterprises}

In order to analyze and understand medium-sized enterprises sources of finances and its capital structures, this paper obtained financial statements for selected three industries from a primary source on both of Limited Liability Company and public listed companies.

Based on the collected data, this paper analyzed 14 companies, three (Note: numbers from 1-10 should be written out in sentances) years financial performances in 3 different industries. Selected industries are based on the majority number of business enterprises. A study is selected 14 enterprises based on the Top Taxpaying Mongolian Small and Medium Enterprises' (2016) by General Department by Taxation, Mongolia and categorized enterprises into 3 industries by business activities. Manufacturing (5), Trading (5) and Service providers (4). In order to keep confidentiality, names of the industries are not given here, instead codes are used. As of 4th quarter, 2015 there are 64, 301 actively operating business registers in Mongolia and based on the World Bank assumption 98\% (63,014) are SMEs (population) based on the registered entities at National Statistics Office of Mongolia. This paper aimed to perform both of qualitative and quantitative analysis for the sources of finances for the selected enterprises, financial performance analysis for 3 consecutive years.

\subsection{Selected Medium-sized Enterprises}

This paper used selection methodology to define selected enterprises of 3 different industries financial statements of medium enterprises including 5 trading, 5 manufacturing and 4 service providing industries of Mongolia, totally 14 enterprises on 3 industries, during 2014 to 2016.

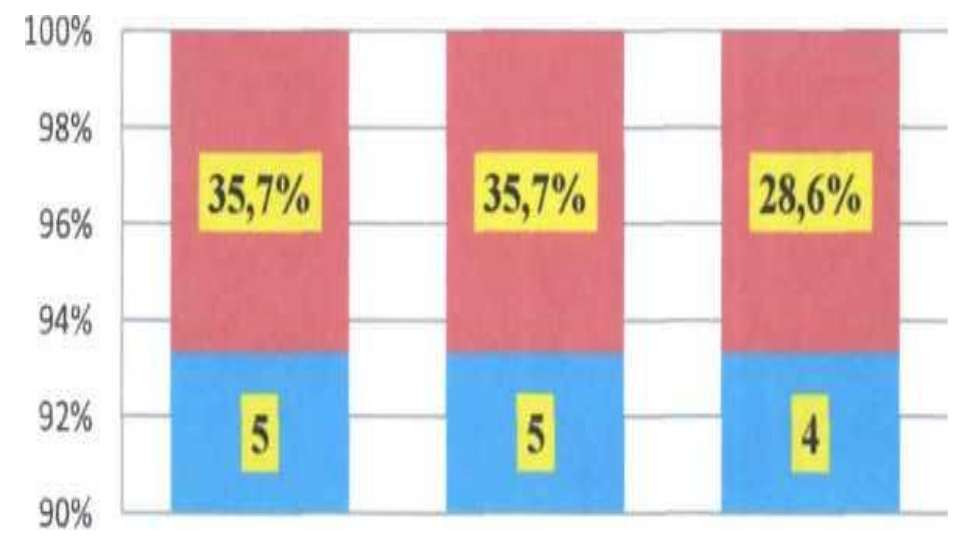

Figure 1. Population of the selected medium-sized enterprises

Trading Manufacturing Service provider

Source: Author's selected industries 


\section{Literature Review}

\subsection{General Review of the Literature}

This chapter reviewed the literature review and theoretical frameworks related with the sources of finances and enterprise capital structures including definition and types/classifications of sources of finances, definition of capital structure, Modigliani-Miller theorem, trade-off and pecking-order and agency theories. The theory of capital structure was initiated by Modigliani and Miller since 1958 discussing on the effect of capital structure on the firm value by concluding their work that the "capital structure is irrelevance" which means that the firm value was not influenced by the financial structure.

\subsection{Introduction to Small and Medium Enterprises (SMEs)}

(Togtokhbuyan Lkhagvasuren, 2014), there is no single, uniformly accepted, definition of a small enterprise (Storey, 1994).

((OECD), 2005), Small and medium-sized enterprises (SMEs) are non-subsidiary, independent firms which employ less than a given number of employees. This number varies across countries. The most frequent upper limit designating an SME is 250 employees, as in the European Union. However, some countries set the limit at 200 employees, while the United States considers SMEs to include firms with fewer than 500 employees.

Essentially, small and medium enterprises definitions measured by firm size such as number of employees and annual turnover and which means firms differ in their levels of capitalization, sales and employment. In Mongolia, 'Law of Small-Medium Enterprise' of Mongolia (adopted in 27 June, 2007), as defined; a business is considered to be an SME if:

- Its number of employees are up to 9-19, annual sales turnover up to 50-250 million tugriks are small enterprises

- Its number of employees are up to 49-199, annual sales turnover up to 1.5 billion tugriks as defined by medium enterprises

Those who engage (Companies that engage...) in manufacturing, wholesaling, retailing, trading, service providing, individual or entities are defined as small and medium enterprises.

Table 1. SME Law of Mongolia (2007)

\begin{tabular}{lllc}
\hline Category & Sector & Number of employees & Annual revenue in MNT \\
\hline Medium & Manufacturing & No more than $>199$ & Up to $>1.5$ billion \\
& Wholesale trade & No more than $>149$ & Upto $>1.5$ billion \\
& Retail trade & No more than $>199$ & Upto $>1.5$ billion \\
& Services & No more than $>49$ & Upto $>1.0$ billion \\
Small & Small Trade/services & No more than $>9$ & Up to $>250$ million \\
& Manufacturing & No more than $>19$ & Up to $>250$ million \\
\hline
\end{tabular}

This paper analyzes external and internal sources of finances for selected 14 medium enterprises on 3 different industries in Mongolia. As of Q4, 2015 (Business register, NSO), there are 64,301 entities are registered at National Statistics Office and those entities are engaged in below industries.

\subsection{Pecking order Hypothesis}

While the trade-off model of corporate leverage has to be considered the "mainstream" choice as the dominant capital structure theory today, there are several regularities in observed corporate behavior that it cannot explain. Three real-world patterns are particularly hard to reconcile with even the most sophisticated trade-off model:

1) Within almost every industry, the most profitable firms have the lowest debt ratios, which is exactly opposite of what the trade-off model predicts;

2) Leverage increasing events, such as a stock repurchase and debt-for-equity exchange offers are almost invariably associated with large positive abnormal returns for a company's stockholders, while leverage-decreasing events lead to stock price declines. According to the trade-off model, these events should both net out to zero abnormal returns, since some firms will be below their "optimal" debt level when they increase leverage, while others will be above the optimum;

3) Firms issue debt securities frequently, but seasoned equity issues are very rare. Announcements of new issues of seasoned equity are invariably greeted with a decline in the firm's stock price (Myers \& Majluf, 1984). Donaldson (1961) has found a pecking order for how firms establish their long-term financing: Firms 
prefer internal financing to external financing of any sort (debt or equity), when financing positive NPV projects. When a firm has insufficient cash flow from internal sources, it sells off part of its investment in marketable securities. As a firm is required to obtain more external financing, it will work down the pecking order of securities, starting with very safe debt, then progressing through risky debt, convertible securities, preferred stock, and lastly common stock.

The pecking order Hypothesis does not provide a formula for calculating an optimal capital structure but it helps to explain observed patterns regarding financing preferences.

Table 2. Number of business register in Mongolia (Q-4, 2015)

\begin{tabular}{ll}
\hline Divisions & $20154 / 4$ \\
\hline Total & 64301 \\
Agriculture, forestry and hunting & 3329 \\
Mining and quarrying & 655 \\
Manufacturing & 5176 \\
Electricity, gas and water supply & 251 \\
Construction & 5390 \\
Wholesale and retail trade, repair of motor vehicles, household goods & 23415 \\
Hotels and restaurants & 1957 \\
Transport, storage and communications & 2296 \\
Financial services & 1830 \\
Real estate, renting and other business activities & 6121 \\
Public administration and defense, compulsory social security & 1434 \\
Education & 2973 \\
Health and social work & 3116 \\
Other community, social and personal services & 6334 \\
Extra-territorial organization and bodies & 24
\end{tabular}

Most of active establishment entities had 1-9 employees and majority of them are limited liability companies as registered by Q3, 2015 (Business register, NSO).

Table 3. Number of business register by employees in Mongolia (Q-3, 2015)

\begin{tabular}{|c|c|c|c|c|}
\hline \multirow[t]{3}{*}{ Business Register } & \multicolumn{4}{|c|}{ Q-3, 2015} \\
\hline & \multicolumn{4}{|c|}{ Number of employees } \\
\hline & $1-9$ & $10-19$ & $20-49$ & $50+$ \\
\hline Total & 54514 & 4936 & 3853 & 2408 \\
\hline
\end{tabular}

World Bank (2014) stated that SMEs make up 98\% of all enterprises in Mongolia (about $80 \%$ of which are microenterprises). They contribute $25 \%$ to GDP and employ $52 \%$ of the workforce.

\subsection{Signaling Hypothesis}

1. What is valued in the market place is the perceived returns for the firm. However, managers of the firm have access to information about the firm that the public does not have access to. Therefore managers might select to use financial policy decisions to convey this information to the market.

2. The signaling Hypothesis suggests that a higher financial leverage can be used by managers to signal an optimistic future for the firm. Unsuccessful firms cannot mimic these signals because such firms do not have sufficient cash flow to back them up (Ross, 1977).

3. The signaling Hypothesis offers a good prediction of the market responses to the different types of security issues. Debt issues are signaling good news, and are greeted with a positive stock price response, while equity issues signal bad news, so that it brings a decline of stock price. However, observed capital structure patterns suggest that the signaling Hypothesis does not predict actual behavior very well. For example, leverage ratios have been found to be inversely related to profitability 
in most industries and not directly related as the signaling Hypothesis predicts them to be.

4. Another proof to be found is that the signaling hypotheses predicts that industries with extensive growth options and other intangible assets should employ more debt than mature and tangible-asset wealthy industries, since growth companies have more severe information asymmetry problems, and therefore have a greater need for signaling. However, the total opposite has been found in empirical studies. It can therefore be concluded that the signaling Hypothesis does not explain the real world of modern corporate finance very well (Megginson, 1997).

\subsection{Optimal Capital Structure}

The optimal capital structure is the mix of debt and equity that maximizes a firm's return on capital, thereby maximizing its value. The target (optimal) capital structure is simply defined as the mix of debt, preferred stock and common equity that will optimize the company's stock price. Capital structure of a firm is determined by various internal and external factors. Following are the main factors which affect the capital structure decision.

\subsection{Factors Determining Capital Structure}

Table 4. Factors determining capital structure

The word "equity" denotes the ownership of the company. Trading on equity means taking advantage of equity share capital to borrowed funds on reasonable basis. It refers to additional profits that equity shareholders earn because of issuance of debentures and

Trading on Equity preference shares. It is based on the thought that if the rate of dividend on preference capital and the rate of interest on borrowed capital is lower than the general rate of company's earnings, equity shareholders are at advantage which means a company should go for a judicious blend of preference shares, equity shares as well as debentures. Trading on equity becomes more important when expectations of shareholders are high.

In a company, it is the directors who are so called elected representatives of equity shareholders. These members have got maximum voting rights in a concern as compared to the preference shareholders and debenture holders. Preference shareholders have

Degree of control reasonably less voting rights while debenture holders have no voting rights. If the company's management policies are such that they want to retain their voting rights in their hands, the capital structure consists of debenture holders and loans rather than equity shares.

In an enterprise, the capital structure should be such that there is both contractions as well as relaxation in plans. Debentures and loans can be refunded back as the time requires.

Flexibility of financial plan While equity capital cannot be refunded at any point which provides rigidity to plans. Therefore, in order to make the capital structure possible, the company should go for issue of debentures and other loans.

The Company's polic y generally is to have different categories of investors for securities. Therefore, a capital structure should give enough choice to all kind of investors to invest.

Choice of investors Bold and adventurous investors generally go for equity shares and loans and debentures are generally raised keeping into mind conscious investors.

In the lifetime of the company, the market price of the shares has got an important

Capital market condition influence. During the depression period, the company's capital structure generally consists of debentures and loans. While in period of boons and inflation, the company's capital should consist of share capital generally equity shares.

Period of financing When company wants to raise finance for short period, it goes for loans from banks and other institutions; while for long period it goes for issue of shares and debentures.

In a capital structure, the company has to look to the factor of cost when securities are

Cost of financing raised. It is seen that debentures at the time of profit earning of company prove to be a cheaper source of finance as compared to equity shares where equity shareholders demand an extra share in profits.

An established business which has a growing market and high sales turnover, the company is in position to meet fixed commitments. Interest on debentures has to be paid regardless of profit. Therefore, when sales are high, thereby the profits are high and

Stability of sales company is in better position to meet such fixed commitments like interest on debentures and dividends on preference shares. If company is having unstable sales, then the company is not in position to meet fixed obligations. So, equity capital proves to be safe in such cases.

Small size business firm's capital structure ge nerally consists of loans from banks and retained profits. While on the other hand, big companies having goodwill, stability and an

Sizes of a company established profit can easily go for issuance of shares and debentures as well as loans and borrowings from financial institutions. The bigger the size, the wider is total capitalization. 


\subsection{Theoretical Frameworkfor Sources of Finances}

\subsubsection{Definition of Sources of Finances}

Finance is the lifeblood of business concern, because it is interlinked with all activities performed by the business concern.

Based on the definition of (C.Paramasivan), sources of finance mean the ways for mobilizing various terms of finance to the industrial concern. Sources of finance state that, how the companies are mobilizing finance for their requirements. The both new and existing companies need amount of financial resources to meet the long-term and short-term requirements such as purchasing of fixed assets, construction of office building, purchase of raw materials and day-to-day expenses.

\subsubsection{Financial Leverage and Capital Structure}

Firm specific factors, firm ownership factors and country specific factors that affect the corporate financing patterns and have impact on firm's financial performance. A firm's capital structure (or financial Based on the above stated theories, this thesis will define an optimal target structure of selected 3 industries, 14 companies.

\subsubsection{Definition of Capital Structure}

Definitions initiated the meaning and objective of the capital structures.

- According to the definition of Gerestenbeg, "Capital Structure of a company refers to the composition or make up of its capitalization and it includes all long-term capital resources".

- According to the definition of James C. Van Home, "The mix of a firm's permanent long-term financing represented by debt, preferred stock, and common stock equity".

- According to the definition of Presana Chandra, "The composition of a firm's financing consists of equity, preference, and debt". 48 Financial Management

- According to the definition of R.H. Wessel, "The long term sources of fund employed in a business enterprise".

Paramasivan defined that (Chapter-5, Financial Management, 2008) capital is the major part of all kinds of business activities, which are decided by the size, and nature of the business concern. Capital may be raised with the help of various sources. If the company maintains proper and adequate level of capital, it will earn high profit and they can provide more dividends to its shareholders.

Financing patterns formal researches started by 2 Nobel laureates, Franco Modigliani and Merton Miller (1958) presented the capital structure irrelevance theory. Modigliani and Miller theory (1958) which was on restrictive assumptions was also under constant focus for other researchers, Myers (1984).

\subsubsection{Modigliani-Miller Theorem}

The theory of business finance in a modern sense starts with the Modigliani and Miller (1958) capital structure irrelevance proposition. Before Modigliani and Miller, there was no generally accepted theory of capital structure.

They start by assuming that the firm has a particular set of expected cash flows. When the firm chooses a certain proportion of debt and equity to finance its assets, all that it does is to divide up the cash flows among investors. Investors and firms are assumed to have equal access to financial markets, which allows for leverage. The investor can create any leverage that was wanted but not offered, or the investor can get rid of any leverage that the firm took on but was not wanted. As a result the leverage of the firm has no effect on the market value of the firm.

There are two fundamentally different types of capital structure irrelevance propositions. The classic arbitrage-based irrelevance propositions provide settings in which arbitrage by investors keeps the value of the firm independent of its leverage.

\subsubsection{Savings and Credit Cooperatives}

According to FRC, there are close to 200 SCCs in Mongolia having an asset size of about USD 40 million in total. Regarding their asset size, SCCs have less than $0.5 \%$ share in Mongolia's financial sector.

SCCs serve about 27,000 customers, most of which are low-income rural households. Similar to NBFIs, SCCs are licensed, regulated, and supervised by the FRC. The services provided by SCCs are: loans (only to members), payment guarantee, currency exchange, remittances, factoring, leasing, short-term investment, trust funds, and 
electronic payments. According to the Mongolian Confederation of Credit Unions, most members of SCCs are women. SCCs clients mostly work in the informal sector and have no capacity to borrow at banks or NBFI

\subsubsection{Support Institutions for SMEs}

Mongolia has recognized the potential of SMEs and has established several programs to support SMEs in the terms of funding and capacity building. The Ministry of Labor (MOL) assumes the overall regulatory role.

The SME Development Department unit at the MOL is the only department authorized by law to undertake the regulatory changes relevant for SMEs. On behalf of the government, the MOL so far has initiated two large-scale national programs for the development of SMEs. While the first program implemented between 1999-2004 prioritized issues related to infrastructure, the second program, launched in 2006 and accomplished in 2012, focused upon enhancement of the legal and policy framework, in particular the law on SMEs, Law on Legal Status of Industries, Law on Science and Technology and the Law on Credit Guarantee Fund enacted in this period.

Other programs launched by MOL were the SME support program and SME support fund, providing training through public bodies and loans at below-market rates through commercial banks. Furthermore, international agencies and NGOs provide various kinds of support to Mongolian SMEs and initiated a series of programs combining capacity building activities and financial support.

\subsubsection{Mongolian Financial Sector Overview}

Mongolian financial sector consists of the banking sector and non-bank financial institutions, (NBFIs) such as, savings and credit cooperatives (SCCs), securities and brokerage firms and insurance companies. (Securities, 2015), financial sector has been and is the fastest growing sector of Mongolia since 2010. It has grown $20 \%$ in 2014 and accounts for 5\% of total GDP of 2014.

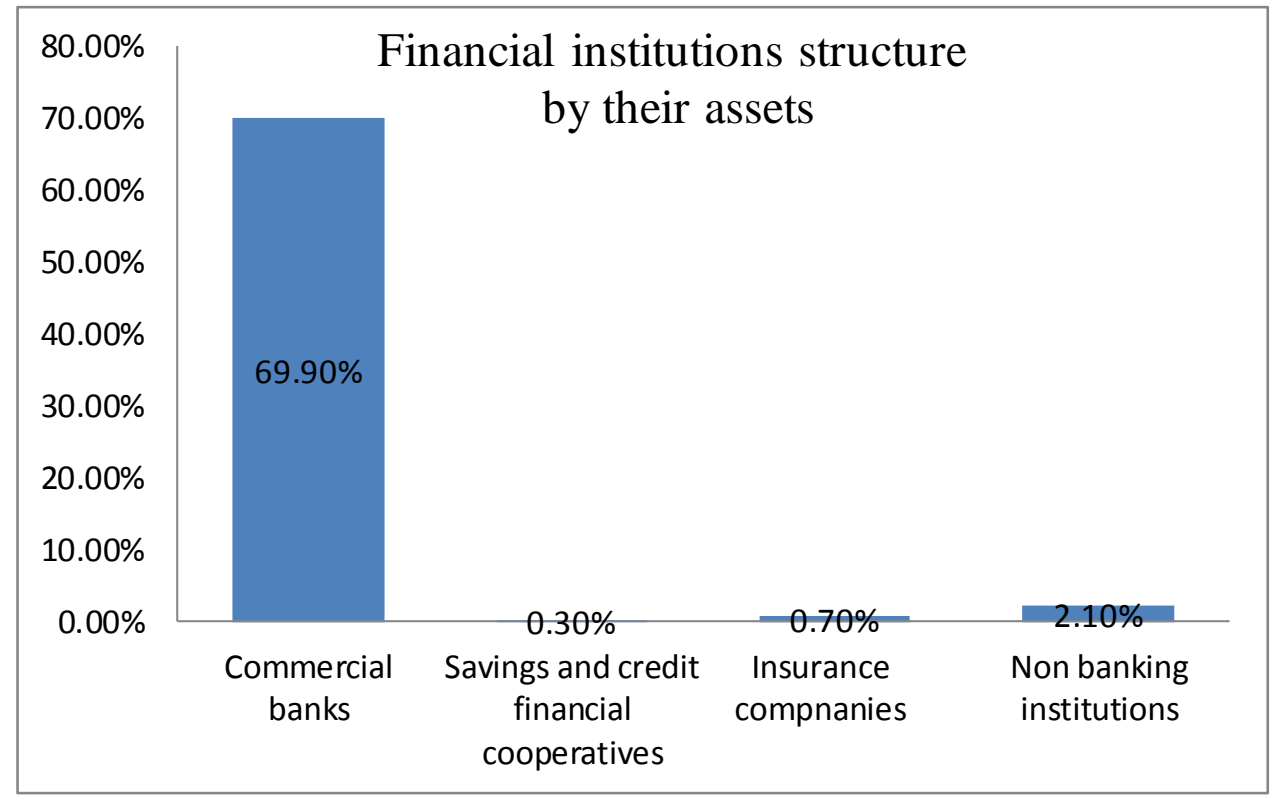

Figure 2. Financial institutions structure by their assets

- As of December 2014, Mongolian financial sector is consisting of 13 commercial banks, 1 development bank, 195 small NBFIs, 159 savings \& credit cooperatives and 17 insurance companies.

- More than $96 \%$ percent of financial sector assets are held by the commercial banks as of 2014.

- According to the consolidated balance of the savings and credit cooperatives as of December 2014 (compiled by the FRC) total asset of the savings and credit cooperatives $80,527.8$ mill tugriks, which accounts for only $3 \%$ of total bank assets.

Total profit of the total savings and credit cooperatives was 3,968.9 million tugriks in 2014, $2.5 \%$ lower than the previous year.

There are totally 17 insurance companies are operating in Mongolia and total assets of these companies reached to $152,522.8$ million in 2014 , which increased by $40.4 \%$ from 2013 level. 


\section{Hypotheses}

\section{Statement of the Hypothesis}

Based on the literature review and theoretical studies, this paper defined below Hypothesis.

1. Hypothesis-1: Sources of finance varies with type of industries

2. Hypothesis-2: Sources of finance varies by enterprise's financial performances

3. Hypothesis-3: Enterprise capital structure varies with type of industries

4. Hypothesis-4: Capital structure varies by type of ownership

5. Hypothesis-5: Optimal capital structure varies by type of industries

\section{Methods and Procedures}

In order to confirm the above Hypothesis, as the first step, all the possible sources of finances, available in literature are listed. Howe ver, during this empirical study, it was observed that all the sources of finances are not exactly used by the Medium Enterprises. Based on the financial statements of the selected Medium enterprises, the following major sources of finances are identified.

\subsection{Data and Methodology}

The financial statements were obtained for selected 14 enterprises and they are categorized into three groups based on their business activities namely Manufacturing (5), Trading (5) and Service providers. From the financial statements, various financial ratios were derived. Using the financial ratios, the enterprises were ranked and categorized as well performing (WP) and non-well performing enterprises (NWP). In the same time, in order to compare a capital structuring, this paper also selected 13 companies who are publicly listed at the Mongolian Stock Exchange and calculated each industry beta that measure the volatility of the security in comparison to the TOP-20 index. Therefore, paper also calculated debt to equity ratio between industries and defined an existing capital structure that is aimed to compare between Limited Liability Company and public listed companies. Last chapter of the paper is defined an optimal capital structure of the selected industries.

The paper carefully analyzed and chosen research methods and techniques are described, including the rationale behind a qualitative research approach. Additionally, the exploited data collection and analysis methods are characterized.

\subsection{Selected Enterprises}

In order to analyze and understand medium-sized enterprises sources of finances and its capital structures, this paper obtained financial statements for selected 3 industries from a primary source on both of Limited Liability Company and public listed companies.

Based on the collected data, this paper analyzed 14 companies, 3 years financial performances in 3 different industries. Selected industries are based on the majority number of business enterprises. A study is selected 14 enterprises based on the Top Taxpaying Mongolian Small and Medium Enterprises" (2014) by General Department by Taxation, Mongolia and categorized enterprises into 3 industries by business activities. Manufacturing (5), Trading (5) and Service providers (4). In order to keep confidentiality, names of the industries are not given here, instead codes are used. As of 4th quarter, 2015 there are 64, 301 actively operating business registers in Mongolia and based on the World Bank assumption 98\% $(63,014)$ are SMEs (population) based on the registered entities at National Statistics Office of Mongolia.

\subsection{Data Collection}

Data collection instruments for this paper are based on the mixture of observation grid study and scenario analysis and assumptions. AH financial statements for the selected enterprises are collected from its primary and secondary sources.

This paper used all reliable and official sources for the data collections. Data collection sources include:

- Online sources (reliable and official sources) such as www.nso.mn, www.1212.mn, www.sme.gov.mn, www.worldbank.com, www.mongolbank.mn, www.oecd.org, www.frc.mn, www.mse.mn, www.mse.mn, www.imf.com etc.,

- Official textbooks (Corporate finance. Fundamental of Financial Management, Research Methods, Statistics etc.,)

- Previous studies and researches (Regarding the financing pattern, capital structure, 
SME etc.,) from EBSCO system

- Scenario analysis and assumptions for selected companies

Data collection process continued 4 weeks after defined all reliable and official sources.

\subsection{Data Analysis}

Data analysis procedures implemented based on the Gant-chart paper project implementation plan. Data analysis process completed 4 weeks after collected all required data. Each process's improvement done by paper mentors guideline on weekly basis.

Literature review and theoretical framework sessions used Mendeley Desktop and sampled company's financial performance analysis calculated at Microsoft Excel.

This paper analysis used below software for data analysis:

- Mendeley Desktop (Free reference manager and PDF organizer)

- Microsoft Word 2010

- Microsoft Excel 2010

- Microsoft ThinkCell 2010

- Microsoft Visio (Professional Flow Chart and Diagram Software)

This paper used arithmetic mean (an average is the sum of a list of numbers divided by the number of numbers in the list) method for financial statement analysis and industry average.

This paper calculated enterprise's financial performance analysis per each enterprise (based on the financial statement 2012-2014). But before calculating ratio analysis, this is calculated average basis on the 3 years data (But, in some cases, depending on the given set of numbers, average is calculated by each year that means in case only 2 years revenue available, calculated 2 years average). Main reason for choose in average is in statistics, an average is defined as the number that measures the central tendency of a given set of numbers. So, in order to measure a central tendency this paper calculated averages per each set of numbers. In order to show an industry tendency it's also calculated

- Mean (arithmetic mean are that helps to measures of central tendency),

- Standard deviation (STDEV) (a measure that is used to quantify the amount of variation or dispersion of a set of data values),

- Coefficient variation (CV) (Measure of the dispersion of data points in a data series around the mean)

- Standard error (SE) (standard deviation of the sampling distribution of a statistic)

- Confidence interval (CI) is a type of interval estimate of a population parameter

\subsection{Limitations and Delimitations}

This paper has a limitation to identify all potential sources of finances for Mongolian medium-sized enterprises. Regarding the sampling, there are also certain limitations and this paper analyzed only 14 companies, 3 years financial performances (2012-2014) in 3 different industries. Any further improvement, it's better to analyze on more enterprises up to 5 different industries, 5 years financial performances by sampling method basis. In order to make an industry comparison researches, it's better to select enterprises by its main business sectors such as mining, construction etc., In this paper, I categorized enterprises into 3 different industries, however some of the selected industries example in manufacture different range of products including socks, textiles, noodles, iron, concrete, etc.,

Initial idea for this paper was to organize an interview based questionnaire for selected companies and explore their existing sources of finances and define some of influential factors to obtain sources of finances. However, this paper is aimed to concentrate on the quantitative analysis for the sources of finances and capital structuring and its optimal structure assumptions. So, all analysis aimed to define existing sources of finances for different industries and its existing capital structure and assumption of an optimal capital structures.

In order to keep selected companies confidentiality, this paper used a $2 \mathrm{x}$ multiplier on the all collected financial statement data that means all calculated primary variables are converted into multiplier before all financial performance calculations. 


\section{Empirical Findings}

This paper is aimed to define sources of finances of different type of industries including trading (5), manufacturing (5) and service providing (4) medium enterprises (total 14 companies) that are actively operating their business during the selected period (2012-2014) in Mongolian market.

\subsection{Hypothesis-1: Sources of Finance Varies with Type of Industries}

In order to confirm above Hypothesis, this research listed all sources of finances on theories. However, during this empirical study all of sources of finances are not exactly used in a real life that approved based on the observatory analysis. Medium enterprises only use below listed sources of finances is commonly that are stated by numeral parameters on their financial statements.

Table 5. Sources of finances by industries

\begin{tabular}{|c|c|c|c|c|c|c|}
\hline & & Trading & $\begin{array}{c}\text { Manufact } \\
\text { uring }\end{array}$ & $\begin{array}{c}\text { Service } \\
\text { providing }\end{array}$ & $\begin{array}{c}\text { Using } \\
\text { sources }\end{array}$ & $\begin{array}{c}\text { Total } \\
\text { companies }\end{array}$ \\
\hline \multirow[t]{4}{*}{ Short term } & Overdrafts & 5 & 4 & 3 & 12 & 14 \\
\hline & Short-term loans & 3 & 3 & 1 & 7 & 14 \\
\hline & Trade credit & & & & 0 & 14 \\
\hline & Leasing & & & & 0 & 14 \\
\hline \multirow[t]{2}{*}{ Long term } & Bonds & 1 & 3 & 1 & 5 & 14 \\
\hline & Security & & & & 0 & 14 \\
\hline $\begin{array}{l}\text { Venture } \\
\text { capital }\end{array}$ & Venture capital & 0 & 3 & 1 & 4 & 14 \\
\hline \multirow{2}{*}{$\begin{array}{l}\text { Equity } \\
\text { finance }\end{array}$} & Ordinary shares & 5 & 5 & 4 & 14 & 14 \\
\hline & Stock market listing & & & & 0 & 14 \\
\hline \multirow{6}{*}{$\begin{array}{l}\text { Internal } \\
\text { sources }\end{array}$} & Retained earnings & 4 & 5 & 3 & 12 & 14 \\
\hline & Increasing WCM efficiency & & & & 0 & 14 \\
\hline & Dividend & & & & 0 & 14 \\
\hline & Stock split & & & & 0 & 14 \\
\hline & Share repurchase & & & & 0 & 14 \\
\hline & Total & 18 & 23 & 13 & 54 & 14 \\
\hline
\end{tabular}

Author's empirical study result

Based on this empirical study, there are only 6 popular sources of finances for medium enterprises that are including, ordinary shares (14 out of 14), overdrafts (14 out of 14), retained earnings (12 out of 14), short-term loans (17 out of 14), bonds (5 out of 14) and venture capitals (4 out of 14). TOP-3 sources of finances are including ordinary shares (100\% of selected industries), overdrafts ( $86 \%$ of selected industries) and retained earnings ( $86 \%$ of selected industries). That means medium enterprise has a trend that mainly uses internal sources including ordinary shares, overdrafts and retained earnings.

Table 6. Top sources of finances by industries

\begin{tabular}{|c|c|c|c|c|c|c|c|c|}
\hline & & Trading & $\begin{array}{c}\text { Manufact } \\
\text { uring }\end{array}$ & $\begin{array}{c}\text { Service } \\
\text { providing }\end{array}$ & $\begin{array}{c}\text { Using } \\
\text { sources }\end{array}$ & $\begin{array}{c}\text { Total } \\
\text { companies }\end{array}$ & $\begin{array}{c}\text { Percent } \\
\text { age }\end{array}$ & Ranking \\
\hline $\begin{array}{l}\text { Equity } \\
\text { finance }\end{array}$ & $\begin{array}{l}\text { Ordinary } \\
\text { shares }\end{array}$ & 5 & 5 & 4 & 14 & 14 & $100 \%$ & 1 \\
\hline Short term & Overdrafts & 5 & 4 & 3 & 12 & 14 & $86 \%$ & 2 \\
\hline $\begin{array}{r}\text { Internal } \\
\text { sources }\end{array}$ & $\begin{array}{l}\text { Retained } \\
\text { earnings }\end{array}$ & 4 & 5 & 3 & 12 & 14 & $86 \%$ & 2 \\
\hline Short term & $\begin{array}{c}\text { Short-term } \\
\text { loans }\end{array}$ & 3 & 3 & 1 & 7 & 14 & $50 \%$ & 3 \\
\hline Long term & Bonds & 1 & 3 & 1 & 5 & 14 & $36 \%$ & 4 \\
\hline \multirow[t]{2}{*}{$\begin{array}{l}\text { Venture } \\
\text { capital }\end{array}$} & $\begin{array}{l}\text { Venture } \\
\text { capital }\end{array}$ & 0 & 3 & 1 & 4 & 14 & $29 \%$ & 5 \\
\hline & Total & 18 & 23 & 13 & 54 & 14 & & \\
\hline
\end{tabular}


Author s empirical study result

In order to approve estimated Hypothesis-1, this paper defined sources of finances by each industry. Howe ver, depending on the industry specific factors, there is a small variation between trading, manufacturing and service providing industries.

Trading companies' sources of finances:

Trading companies use 5 different sources of finances including ordinary shares ( 5 of 5 ), overdrafts ( 5 of 5 ) and retained earnings ( 4 of 5). 3 of 5 trading companies are using short-term loans, 1 of 5 companies is using bonds (long-term loans) and 0 of 5 companies are using venture capitals.

\section{Trading companies sources of finances}

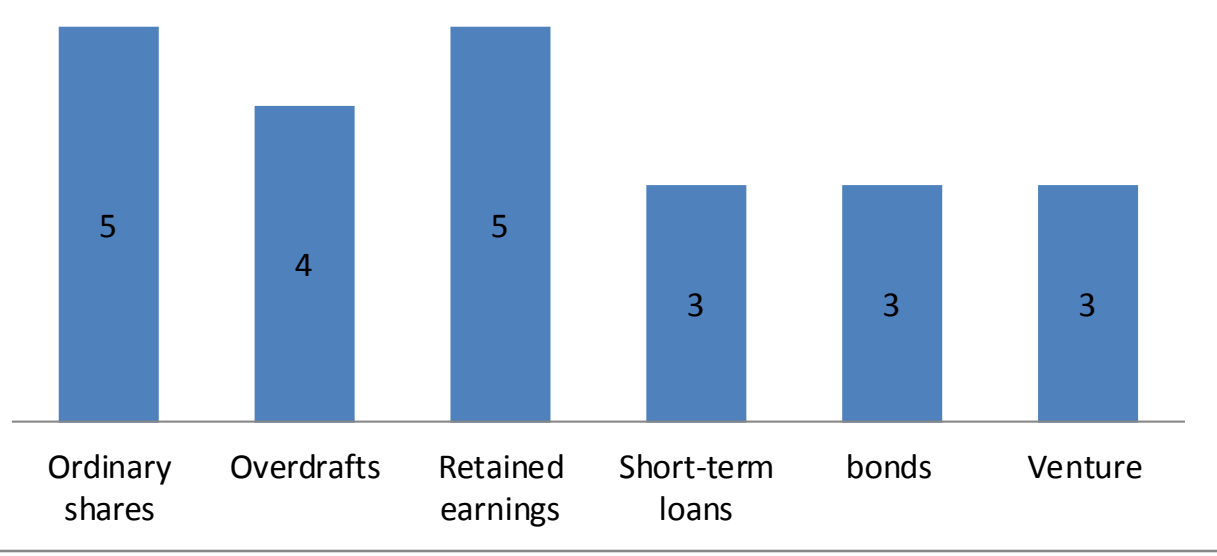

Figure 3. Top sources of finances by industries

\section{Source: Author's empirical study result}

There is a general trend of trading companies from the above list, trading companies mainly uses ordinary shares, overdrafts and retained earnings, but depending on the type of business activity and range of product, short-term loan and bonds look the popular sources in this area.

Manufacturing companies sources of finances:

Manufacturing companies are using 6 different sources of finances including ordinary shares (5 of 5), retained earnings ( 5 of 5), overdrafts ( 4 of 5), short-term loans ( 3 of 5), bonds ( 3 of 5) and venture capital (3 of 5).

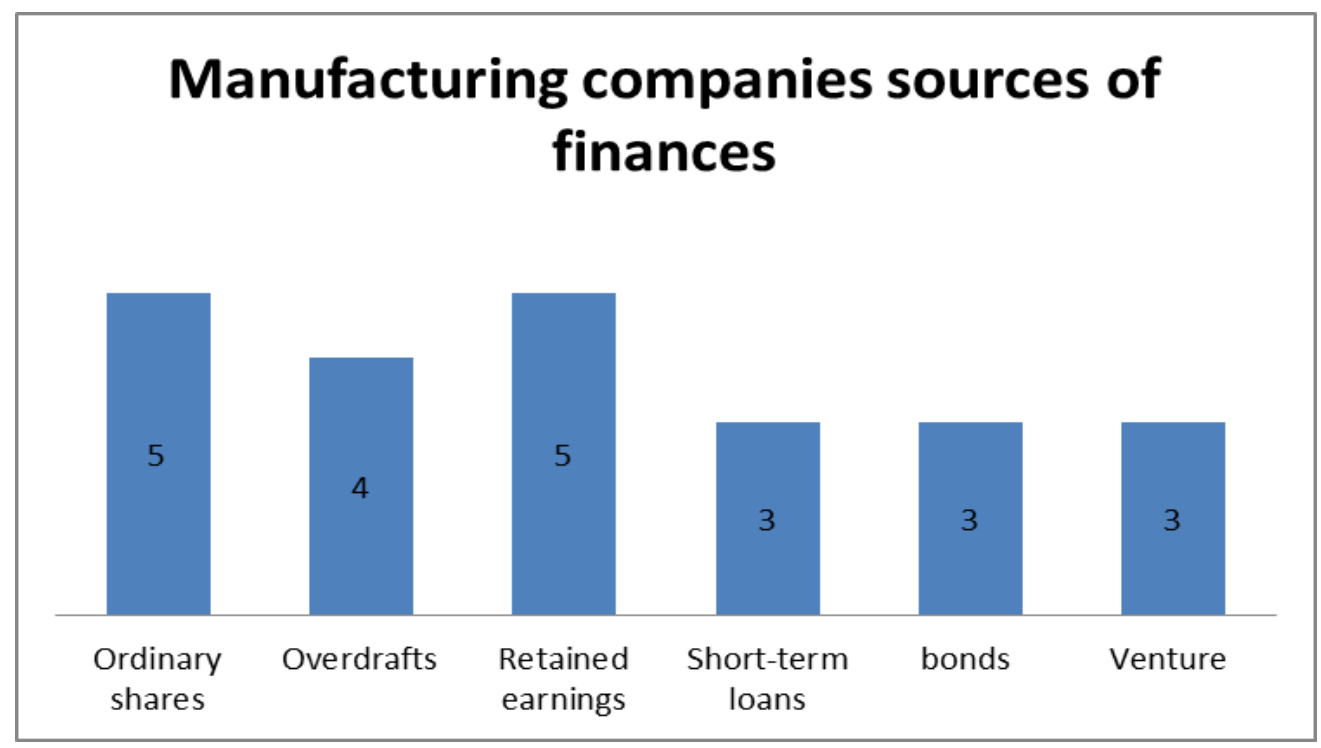

Figure 4. Manufacturing companies sources of finances 


\section{Author's empirical study result}

Manufacturing companies' common sources of finances are defined by both of external and internal sources. Based on this observation study, manufacturing companies mainly use internal sources of finances including ordinary shares, retained earnings and overdrafts. And over $60 \%$ of selected manufacturing companies use external sources of finances thorough financial leverages such as bonds (long-term loans) and short term loans and venture capitals.

\subsubsection{Service Providing Companies' Sources of Finances}

Service providing companies are also using 6 different sources of finances including ordinary shares (4 of 4), overdrafts ( 3 of 4$)$, retained earnings ( 3 of 4$)$, short-term loans ( 1 of 4$)$, bonds ( 1 of 4 ) and venture capital ( 1 of 4).

\section{Comparison of sources of finances between industries}

This paper shown a number of sources of finances by type of industries, but there is no difference on the number of sources of finances and all 3 type of industries including trading (5), manufacturing (5) and service providing (4) companies are all using 6 same type of sources of finances on their operation.

Table 7. Comparison of sources of finances between industries

\begin{tabular}{llccc}
\hline & & Trading & Manufacturing & $\begin{array}{c}\text { Service } \\
\text { providing }\end{array}$ \\
\hline Equity finance & Ordinary shares & 5 & 5 & 4 \\
Short term & Overdrafts & 5 & 4 & 3 \\
Internal & Retained earnings & 4 & 5 & 3 \\
sources & & & 3 & 1 \\
Short term & Short-term loans & 3 & 3 & 1 \\
Long term & Bonds & 1 & $?$ & 13 \\
Venture capital & Venture capital & 0 & 23 & 24 \\
& Using sources & 18 & 30 & 13 \\
\hline
\end{tabular}

Source: Author's empirical study result

But, comparing with trading an service providing industries, manufacturing companies are using 6 types, 23 sources out of 30 that means who uses higher financial leverages on their activity. Trading industry uses much lower financial leverages from external sources and who mainly uses internal and short term sources. Trading companies uses 5 types, 18 sources out of 30 who mainly use internal sources of finances including ordinary shares, overdrafts and retained earnings.

\subsection{Hypothesis-2: Sources of Finance Varies by Enterprise's Financial Performances}

In order to approve above Hypothesis, this paper analyzed financial performances of the selected 3 industries 14 companies based on financial statement of 2012-2014. Generally, financial performance analysis is the process of identifying the financial strengths and weaknesses of the firm, in order to evaluate financial condition and performance of the selected medium enterprises, this paper used financial ratio analysis that is one of the widely used and powerful tools.

This paper ratio analysis is classified into below 5 broad groups:

This paper calculated above stated financial performance analysis per each enterprise (based on the financial statement 2012-2014). But before calculating ratio analysis, this is calculated average basis on the 3 years data (But, in some cases, depending on the collected set of numbers, average is calculated by each year that means in case if only 2 years revenue are available, calculated 2 years average only).

Main reason for choose in average is in statistics, an average is defined as the number that measures the central tendency of a given set of numbers. So, in order to measure a central tendency this paper calculated averages per each set of numbers. 
Table 8. Financial ratio analysis

\begin{tabular}{|c|c|c|c|c|}
\hline № & Group & Ratio & Formula & Description \\
\hline 2 & $\begin{array}{l}\text { Liquidity } \\
\text { Ratios }\end{array}$ & $\begin{array}{l}\text { Quick (Acid } \\
\text { test) ratio }\end{array}$ & $\begin{array}{l}\text { Current asset/current liabilities } \\
\text { Current } \\
\text { asset-inventory/current liabilities }\end{array}$ & $\begin{array}{c}\text { Measures the amount of liquidity available to pay } \\
\text { for current liabilities } \\
\text { Strong indicator of whether a firm has sufficient } \\
\text { short-term assets to cover its immediate } \\
\text { liabilities }\end{array}$ \\
\hline 3 & & $\begin{array}{l}\text { Inventory } \\
\text { turnover ratio }\end{array}$ & COGS/Average inventory & $\begin{array}{l}\text { Measures the amount of inventory needed to } \\
\text { support a given level of sales }\end{array}$ \\
\hline 4 & & $\begin{array}{l}\text { Receivable } \\
\text { turnover ratio }\end{array}$ & Sales/Average receivable & $\begin{array}{c}\text { Activity ratio measuring how efficiently a firm } \\
\text { uses its assets }\end{array}$ \\
\hline 5 & $\begin{array}{c}\text { Working } \\
\text { Capital Ratios }\end{array}$ & $\begin{array}{l}\text { Payable } \\
\text { turnover ratio }\end{array}$ & $\begin{array}{l}\text { Cost of Goods Sold/Average } \\
\text { payables }\end{array}$ & $\begin{array}{l}\text { Measures the speed with which a company pays } \\
\text { its suppliers. }\end{array}$ \\
\hline 6 & & Cash ratio & Cash/current liability & $\begin{array}{l}\text { An indicator of a company's liquidity that further } \\
\text { refines both the current ratio and the quick ratio } \\
\text { by measuring the amount of cash, cash } \\
\text { equivalents or invested funds there are in current } \\
\text { assets to cover current liabilities }\end{array}$ \\
\hline 7 & & $\begin{array}{l}\text { Gross Profit } \\
\text { Margin }\end{array}$ & (Sales - COGS) / Sales & $\begin{array}{l}\text { Shows revenues minus the cost of goods sold, as } \\
\text { a proportion of sales }\end{array}$ \\
\hline 8 & & $\begin{array}{c}\text { Operating } \\
\text { Profit Margin }\end{array}$ & $\begin{array}{l}\text { (Sales COGS-Operating } \\
\text { Expenses) / Sales }\end{array}$ & $\begin{array}{l}\text { A margin ratio used to measure a company's } \\
\text { pricing strategy and operating efficiency }\end{array}$ \\
\hline 9 & Ratios & $\begin{array}{l}\text { Net Profit } \\
\text { Margin }\end{array}$ & $\begin{array}{l}\text { Net income-interest } \\
\text { expense-Foreign exchange rate } \\
\text { gains (losses)/sales }\end{array}$ & $\begin{array}{l}\text { Calculates the amount of profit after taxes and all } \\
\text { expenses have been deducted from net sales }\end{array}$ \\
\hline 10 & & $\begin{array}{l}\text { Total asset } \\
\text { turnover }\end{array}$ & Sales/Total assets & $\begin{array}{l}\text { The value of a company's sales or revenues } \\
\text { generated relative to the value of its assets }\end{array}$ \\
\hline 11 & $\begin{array}{l}\text { Solvency } \\
\text { Ratios }\end{array}$ & $\begin{array}{l}\text { Return on } \\
\text { Equity } \\
\text { (ROE) }\end{array}$ & $\begin{array}{c}\text { Net Income-Interest } \\
\text { expense-Foreign exchange rate } \\
\text { gains (losses)/Shareholder's } \\
\text { Equity }\end{array}$ & Shows company profit as a percentage of equity \\
\hline 12 & & $\begin{array}{c}\text { Return on } \\
\text { Asset (ROA) } \\
\end{array}$ & Net profit/total asset & $\begin{array}{c}\text { Shows company profits as a percentage of fixed } \\
\text { assets and working capital }\end{array}$ \\
\hline 13 & & Debt ratio & $\begin{array}{l}\text { Total assets-Total equity)/Total } \\
\text { assets }\end{array}$ & $\begin{array}{l}\text { Shows the extent to which management is } \\
\text { willing to fund operations with debt, rather than } \\
\text { equity }\end{array}$ \\
\hline 14 & Financial & $\begin{array}{l}\text { Times } \\
\text { Interest } \\
\text { Earned }\end{array}$ & EBIT/ interest expense & $\begin{array}{l}\text { A metric used to measure a company's ability to } \\
\text { meet its debt obligations }\end{array}$ \\
\hline 15 & $\begin{array}{l}\text { Leverage } \\
\text { Ratios }\end{array}$ & $\begin{array}{l}\text { Short-term } \\
\text { Debt Ratio }\end{array}$ & Short term debt/Total asset & $\begin{array}{l}\text { Comprised of any debt incurred by a company } \\
\text { that is due within one year }\end{array}$ \\
\hline 16 & & $\begin{array}{l}\text { Long-term } \\
\text { Debt Ratio }\end{array}$ & Long term debt/Total asset & $\begin{array}{l}\text { A measurement representing the percentage of a } \\
\text { corporation's assets that are financed with loans } \\
\text { and financial obligations lasting more than one } \\
\text { year }\end{array}$ \\
\hline
\end{tabular}

In order to show an industry tendency it's also calculated

- $\quad$ Mean (arithmetic mean are that helps to measures of central tendency)

- Standard de viation (STDEV) (a measure that is used to quantify the amount of variation or dispersion of a set of data values)

- Coefficient variation(CV) (Measure of the dispersion of data points in a data series around the mean)

- $\quad$ Standard error (SE) (standard deviation of the sampling distribution of a statistic)

\subsubsection{Manufacturing Companies Financial Performance and Descriptive Analysis}

Below table shows each manufacturing companies financial performance analysis. Selected 5 manufacturing companies produce different range of products and depending on the product range and business feature, general performance shows as below: There are general tendency that manufacturing companies have higher inventories and receivables, higher profit abilities and uses financial leverages (both of short and long-term debt sources). 
Table 9. Manufacturing companies financial performance and descriptive analysis

\begin{tabular}{|c|c|c|c|c|c|c|c|c|c|c|}
\hline & & $\begin{array}{c}\text { Ml } \\
\text { RATIO }\end{array}$ & $\begin{array}{c}\text { M2 } \\
\text { RATIO }\end{array}$ & $\begin{array}{c}\text { M3 } \\
\text { RATIO }\end{array}$ & $\begin{array}{r}\text { M4 } \\
\text { RATIO }\end{array}$ & $\begin{array}{c}\text { M5 } \\
\text { RATIO }\end{array}$ & MEAN & STDEV & $\mathrm{CV}$ & SE \\
\hline & \multicolumn{10}{|c|}{ LIQUIDITY RATIOS } \\
\hline 1 & Current ratio & 1,42 & 1,93 & 0,88 & 5,47 & 3,41 & 2,6 & 1,85 & 71 & 0,83 \\
\hline 2 & Quick (Acid test) ratio & 0,69 & 1,59 & 0,50 & 5,01 & 0,88 & 1,7 & 1,88 & 109 & 0,84 \\
\hline \multicolumn{11}{|c|}{ WORKING CAPITAL RATIOS } \\
\hline 3 & Inventory turnover & 3,90 & 20,82 & 2,31 & 16,55 & 2,20 & 9,2 & 8,86 & 97 & 3,96 \\
\hline 4 & $\begin{array}{l}\text { Receivable } \\
\text { turnover ratio }\end{array}$ & 8,98 & 26,97 & 15,37 & 19,52 & 0,00 & 14,2 & 10,27 & 72 & 4,59 \\
\hline 5 & Payable turnover ratio & 12,47 & 27,67 & 6,72 & 0,05 & 0,00 & 9,4 & 11,47 & 122 & 5,13 \\
\hline 6 & Cash ratio & 0,12 & 0,13 & 0,01 & 1,84 & 0,87 & 0,6 & 0,78 & 130 & 0,35 \\
\hline \multicolumn{11}{|c|}{ PROFIT ABILITY RATIOS } \\
\hline 7 & Gross Profit Margin & 0,18 & 0,22 & 0,44 & 0,18 & 0,82 & 0,4 & 0,28 & 74 & 0,12 \\
\hline 8 & Operating Profit Margin & 0,03 & 0,21 & $-0,20$ & 0,06 & 0,28 & 0,1 & 0,18 & 246 & 0,08 \\
\hline 9 & Net Profit Margin & $-0,02$ & 0,21 & 0,00 & 0,06 & 0,21 & 0,1 & 0,11 & 122 & 0,05 \\
\hline 10 & Total asset turnover & 2,00 & 1,70 & 1,11 & 0,91 & 0,74 & 1,3 & 0,54 & 42 & 0,24 \\
\hline \multicolumn{11}{|c|}{ SOLVENCY RATIOS } \\
\hline 11 & Return on Equity (ROE) & $-0,02$ & 0,43 & 0,08 & 0,09 & 0,37 & 0,2 & 0,20 & 104 & 0,09 \\
\hline 12 & Return on Asset (ROA) & $-0 . d 2$ & 0,35 & 0,03 & 0,06 & 0,20 & 0,1 & 0,15 & 122 & 0,07 \\
\hline \multicolumn{11}{|c|}{ FINANCIAL LEVERAGE MTIOS } \\
\hline 13 & Debt ratio & 1,00 & 0,18 & 0,71 & 0,47 & 0,63 & 0,6 & 0,30 & 50 & 0,13 \\
\hline 14 & Times Interest Earned & $-0,21$ & 0,00 & 0,00 & 0,00 & 0,25 & 0,0 & 0,16 & 1861 & 0,07 \\
\hline 15 & Short-term Debt Ratio & 0,57 & 0,18 & 0,71 & 0,10 & 0,02 & 0,3 & 0,30 & 96 & 0,14 \\
\hline 16 & Long-term Debt Ratio & 1,28 & 0,00 & 0,00 & 0,37 & 0,60 & 0,4 & 0,53 & 117 & 0,24 \\
\hline
\end{tabular}

5.2.2 Trading Companies' Financial Performance Analysis

The table below shows each trading company's financial performance analysis. Trading companies have a tendency that including higher inventory, higher total asset turnover and mainly use short term debt sources.

Table 10. Trading companies' financial performance analysis

\begin{tabular}{|c|c|c|c|c|c|c|c|c|c|c|}
\hline & & $\begin{array}{c}\text { Tl } \\
\text { RATIO }\end{array}$ & $\begin{array}{c}\mathrm{T} 2 \\
\text { RATIO }\end{array}$ & $\begin{array}{c}\text { T3 } \\
\text { RATIO }\end{array}$ & $\begin{array}{c}\text { T4 } \\
\text { RATIO }\end{array}$ & $\begin{array}{c}\text { T5 } \\
\text { RATIO }\end{array}$ & MEAN & STDEV & $\mathrm{CV}$ & SE \\
\hline & \multicolumn{10}{|c|}{ LIQUIDITY RATIOS } \\
\hline 1 & Current ratio & 0,83 & 0,99 & 2,38 & 0,55 & 2,08 & 1,4 & 0,81 & 60 & 0,36 \\
\hline 2 & Quick (Acid test) ratio & 0,32 & 0,17 & 1,21 & 0.40 & 1.71 & 0,8 & 0,67 & 88 & 0,30 \\
\hline \multicolumn{11}{|c|}{ WORKING CAPITAL RATIOS } \\
\hline 3 & $\begin{array}{l}\text { Inventory turnover } \\
\text { ratio }\end{array}$ & 3,59 & 1,99 & 1,85 & 2,37 & 11,93 & 4,3 & 4,29 & 99 & 1,92 \\
\hline 4 & $\begin{array}{l}\text { Receivable turnover } \\
\text { ratio }\end{array}$ & 394,12 & 601,82 & 3,09 & 1,80 & 9,59 & 202,1 & 279,93 & 139 & $\begin{array}{c}125,1 \\
9\end{array}$ \\
\hline 5 & Payable turnover ratio & 3,19 & 1,72 & 0,43 & 1,03 & 0,06 & 1,3 & 1,23 & 96 & 0,55 \\
\hline 6 & Cash ratio & 0,19 & 0,13 & 0,20 & 0,02 & 0,07 & 0,1 & 0,08 & 64 & 0,04 \\
\hline \multicolumn{11}{|c|}{ PROFIT ABILITY RATIOS } \\
\hline 7 & Gross Profit Margin & 0,34 & 0,62 & 0,30 & 0,15 & 0,24 & 0,3 & 0,18 & 53 & 0,08 \\
\hline
\end{tabular}

The table below shows each service providing company's financial performance analysis and main features that have higher current and quick ratio, lower inventory and receivables and mainly have short-term debt sources. 
Table 11. Service providing company's financial performance analysis

\begin{tabular}{|c|c|c|c|c|c|c|c|c|c|}
\hline & & $\begin{array}{c}\text { SI } \\
\text { RATIO }\end{array}$ & $\begin{array}{c}\text { S2 } \\
\text { RATIO }\end{array}$ & $\begin{array}{c}\text { S3 } \\
\text { RATIO }\end{array}$ & $\begin{array}{c}\text { S4 } \\
\text { RATIO }\end{array}$ & MEAN & STDEV & $\mathrm{CV}$ & SE \\
\hline & \multicolumn{9}{|c|}{ LIQUIDITY RATIOS } \\
\hline 1 & Current ratio & 1,91 & 17,55 & 0,74 & 10,70 & 7,7 & 7,91 & 102 & 3,96 \\
\hline & Quick (Acid test) ratio & 1,59 & 10,32 & 0,49 & 8,96 & 5,3 & 5,02 & 94 & 2,51 \\
\hline & \multicolumn{9}{|c|}{ WORKING CAPITAL RATIOS } \\
\hline 3 & Inventory turnover ratio & 11,46 & 1,95 & 1,39 & 0,95 & 3,9 & 5,03 & 128 & 2,52 \\
\hline 4 & Receivable turnover ratio & 2,97 & 10,09 & 4.30 & 1.30 & 4,7 & 3,82 & 82 & 1,91 \\
\hline 5 & Payable turnover ratio & 8,14 & 0,00 & 0,59 & 0,42 & 2,3 & 3,91 & 171 & 1,95 \\
\hline \multirow[t]{2}{*}{6} & Cash ratio & 0,02 & 4.06 & 0,03 & 1,45 & 1,6 & 2,33 & 144 & 1.16 \\
\hline & \multicolumn{9}{|c|}{ PROFITABILITY RATIOS } \\
\hline 7 & Gross Profit Margin & 0,17 & 0,72 & 0,41 & 0,82 & 0,5 & 0,29 & 56 & 0,15 \\
\hline 8 & Operating Profit Margin & 0,06 & 0,31 & $-0,73$ & 0,22 & 0,0 & 0,48 & 1315 & 0,24 \\
\hline 9 & Net Profit Margin & 0,07 & 0,32 & $-0,78$ & 0,27 & 0,0 & 0,51 & 1710 & 0,26 \\
\hline \multirow[t]{2}{*}{10} & Total asset turnover & 2,28 & 1,08 & 0,26 & 0,37 & 1,0 & 0,93 & 93 & 0,47 \\
\hline & \multicolumn{9}{|c|}{ SOLVENCY RATIOS } \\
\hline 11 & Return on Equity (ROE) & 0,30 & 0,31 & $-2,17$ & 0,09 & $-0,4$ & 1,21 & -329 & 0,60 \\
\hline \multirow[t]{2}{*}{12} & Return on Asset (ROA) & 0,19 & 0,34 & $-0,27$ & 0,10 & 0,1 & 0.26 & 289 & 0,13 \\
\hline & \multicolumn{9}{|c|}{ FINANCIAL LEVERAGE RATIOS } \\
\hline $\mathrm{Li}$ & Debt ratio & 0,52 & 0,02 & 0,91 & 0,04 & 0,4 & 0,42 & 114 & 0,21 \\
\hline 14 & Times Interest Earned & 14,96 & 0,00 & $-0,03$ & 0,00 & 3,7 & 7,48 & 200 & 3,74 \\
\hline & Short-term Debt Ratio & 0,52 & 0,02 & 0,44 & 0,04 & 0,3 & 0,26 & 102 & 0,13 \\
\hline 16 & Long-term Debt Ratio & 0,00 & 0,00 & 0,47 & 0,00 & 0,1 & 0,23 & 200 & 0,12 \\
\hline
\end{tabular}

5.3 Hypothesis-3: Enterprise Capital Structure Varies with Type of Industries

In order to approve, H-3, this paper defined an existing capital structures of the selected 3 industries 14 companies based on the 2014 financial statement data.

Table 12. Manufacturing industry existing capital structures

\begin{tabular}{llllllll}
\hline D/E ratio & M1 & M2 & M3 & M4 & M5 & Average & Median \\
\cline { 2 - 7 } Equity & 1,00 & 0,18 & 0,71 & 0,47 & 0,63 & 0,60 & 0,63 \\
& 1,1 & 0,11 & 0,64 & 0,56 & 0,47 & 0,56 & 0,56 \\
& $-0,01$ & 0,89 & 0,36 & 0,44 & 0,53 & 0,44 & 0,44 \\
\hline
\end{tabular}

Manufacturing industries existing capital structure showed by the mixture of 56\% debt and $44 \%$ equity from the empirical study.

Table 13. Trading industry existing capital structures

\begin{tabular}{lccccccc}
\hline D/E ratio & $\mathrm{T}$ & $\mathrm{T} 2$ & $\mathrm{~T} 3$ & $\mathrm{~T} 4$ & $\mathrm{~T} 5$ & Average & Median \\
\cline { 2 - 8 } Debt & $64 \%$ & $66 \%$ & $40 \%$ & $110 \%$ & $48 \%$ & 0,66 & 0,64 \\
Equity & 0,69 & 0,66 & 0,42 & 1,10 & 0,48 & 0,67 & 0,66 \\
& 0,31 & 0,34 & 0,58 & $-0,10$ & 0,52 & 0,33 & 0,34 \\
\hline
\end{tabular}

Source: Author's empirical study result

Trading industries existing capital structure showed by the mixture of $67 \%$ debt and $33 \%$ equity from the empirical study.

Table 14. Service providing industry existing capital structures

\begin{tabular}{lcccccc}
\hline D/E ratio & SI & S2 & S3 & S4 & Average & Median \\
\cline { 2 - 6 } Debt & $52 \%$ & $2 \%$ & $91 \%$ & $4 \%$ & 0,37 & 0,28 \\
Equity & 0,52 & 0,02 & 1,22 & 0,04 & 0,45 & 0,28 \\
& 0,48 & 0,98 & $-0,22$ & 0,96 & 0,55 & 0,72 \\
\hline
\end{tabular}


Service providing industries existing capital structure shown by mixture of $45 \%$ debt and $55 \%$ equity from this empirical study.

\subsection{Hypothesis-4: Capital Structure Varies by Type of Ownership}

In order to approve above Hypothesis, this paper obtained 13 industries financial statements and historical prices of securities from 2012-2014 from MSE. Selected 13 companies categorized into manufacturing (5), trading (3) and service providing (5) are classified into I and II classifications by MSE and calculate each industry beta and debt-to-equity ratios. Industry beta is used to calculate cost of equity by Capital Asset Pricing Model (CAPM) model and therefore than can be used for scenario analysis to define an optimal capital structure by industries. Debt-to-equity ratio is used to define an existing capital structure of public listed companies and therefore help to make comparison between Limited Liability Company and public listed companies.

\section{Mongolian Stock Exchange}

Mongolian Stock Exchange (MSE) located in Ulaanbaatar, is Mongolia's sole stock exchange. It was established in January 1991 by the decree of the Mongolian Government to privatize state-owned assets. As of 24 April, 2016 there are 235 companies are listed at the MSE and categorized into I classification - 1, II classification - 86, III classification - 148 .

Table 15. Mongolian Stock Exchange

\begin{tabular}{|c|c|c|}
\hline 1 classification & 11 classification & III classification \\
\hline $\begin{array}{l}\text { Classification have companies who } \\
\text { introduced corporate governance } \\
\text { principles and market capitalization is } \\
\text { more than } 10.0 \text { billion MNT and public } \\
\text { ownership is more than } 25 \% \text { with high } \\
\text { liquidity, prestigious and profit abilities. }\end{array}$ & $\begin{array}{l}\text { Classification mainly consists of small } \\
\text { and medium-size enterprises who trade } \\
\text { securities constantly at the MSE and market } \\
\text { value of is more } 0.5 \text { billion MNT and less } \\
\text { than } 2 \text { years stable business activities. }\end{array}$ & $\begin{array}{l}\text { Classification includes higher risky small } \\
\text { and medium enterprises and } 100 \% \\
\text { state-owned companies or on-hold } \\
\text { companies at the securities market by } \\
\text { Financial regulatory Committee. }\end{array}$ \\
\hline
\end{tabular}

1 company 86 companies 148 companies

In order to see public listed companies existing capital structures this paper selected below 13 companies on manufacturing, trading and service providing industries.

\subsection{Hypothesis-5: Optimal Capital Structure Varies by Type of Industries}

As stated in the H-3, this paper defined an existing capital structure by 14 enterprises and 3 industries. This Hypothesis is assumed an optimal capital structure for selected manufacturing, trading and service providing industries. So, in order to approve $\mathrm{H}-5$, this paper calculated each industries optimal capital structures by scenario analysis assumption.

Before assuming an optimal capital structure of the industries, this paper defined a range of assumption based on the confidence interval that is a type of interval estimate of a population parameter.

Table 16. Scenario analysis range assumption by confidence interval

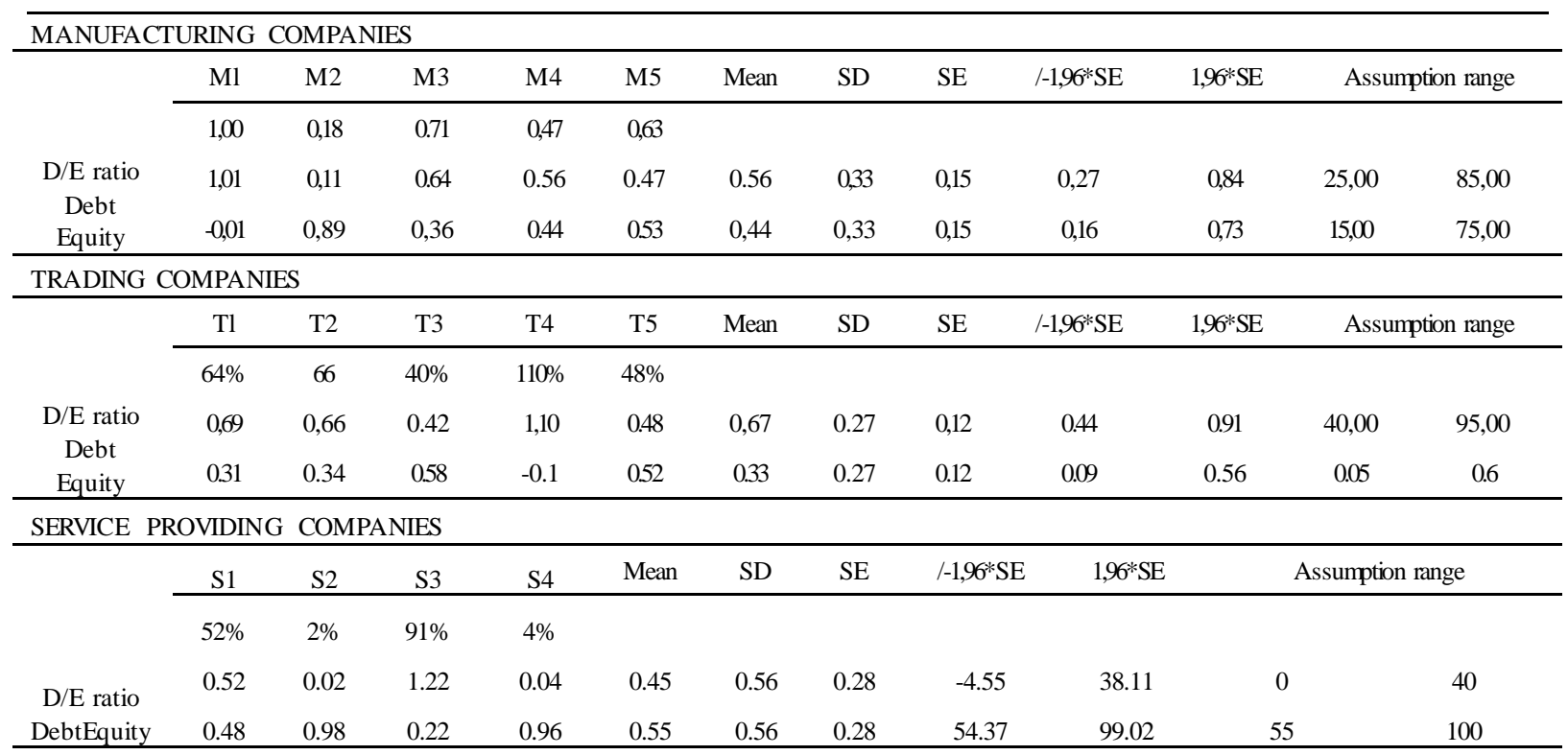


The capital structure analysis will use the cost of capital approach that considers cost of debt and cost of equity. Then the weighted average cost of capital will be calculated which will affect the value of the firm calculation. The optimal capital structure analysis will be done by using scenario analysis. This method provides several possible scenarios in cost of debt and equity calculation.

In order to calculate a cost of equity, this paper calculated industry beta by all of manufacturing, trading and service providing industries. Beta is a measure of the volatility, or systematic risk, of a security or a portfolio in comparison to the market as a whole. Beta is used in the capital asset pricing model (CAPM), a model that calculates the expected return of an asset based on its beta and expected market returns.

\section{Conclusion and Recommendations}

\subsection{Conclusion}

In this analysis, I explored external and internal sources of finance for selected 3 industries 14 companies and defined its existing capital structure and optimal structure. Below are conclusions for each Hypothesis:

\subsubsection{Hypothesis-1 Conclusion}

Based on $\mathrm{H}-\mathrm{l}$ analyses, sources of finance don't vary by industries on an empirical study. However, depending on the certain industry and its features, proportion of sources of finances varies by industries. Based on the empirical study, ordinary shares, overdrafts and retained earnings are listed on the TOP-3 sources of trading, manufacturing and service providing industries.

Table 17. Hypothesis-1 conclusion

\begin{tabular}{|c|c|c|c|c|c|}
\hline & & $\begin{array}{l}\text { TOP-3 } \\
\text { source }\end{array}$ & Trading & Manufacturing & $\begin{array}{c}\text { Service } \\
\text { providing }\end{array}$ \\
\hline Equity finance & Ordinary shares & $\begin{array}{l}\text { TOP-1 } \\
\text { source }\end{array}$ & 5 & 5 & 4 \\
\hline Short term & Overdrafts & $\begin{array}{l}\text { TOP-2 } \\
\text { source }\end{array}$ & 5 & 4 & 3 \\
\hline Internal sources & $\begin{array}{l}\text { Retained } \\
\text { earnings }\end{array}$ & $\begin{array}{l}\text { TOP-3 } \\
\text { source }\end{array}$ & 4 & 5 & 3 \\
\hline
\end{tabular}

Source: Author's empirical study result

\subsubsection{Hypothesis-2 Conclusion}

After this financial performance analysis and overall ranking, service providing industry is still listed at No-1 who uses equity finance, short-term debt and retained earnings. But, all 3 industries equally use above stated financial sources that doesn't vary by industries.

Table 18. Total ranking scores by type of industries

\begin{tabular}{ccccccccc}
\hline Manufacturing & $\begin{array}{c}\text { Total } \\
\text { scores }\end{array}$ & Ranking & Trading & $\begin{array}{c}\text { Total } \\
\text { scores }\end{array}$ & Ranking & $\begin{array}{c}\text { Service } \\
\text { providing }\end{array}$ & $\begin{array}{c}\text { Total } \\
\text { scores }\end{array}$ & Ranking \\
\hline M1 & 152,5 & 11 & $\mathrm{~T} 1$ & 124 & 9 & $\mathrm{SI}$ & 99,5 & 6 \\
M2 & 85,5 & 2 & $\mathrm{~T} 2$ & 129 & 10 & $\mathrm{~S} 2$ & 78 & 1 \\
M3 & 153,5 & 12 & $\mathrm{~T} 3$ & 115,5 & 7 & $\mathrm{~S} 3$ & 176 & 14 \\
M4 & 118,5 & 8 & $\mathrm{~T} 4$ & 170,5 & 13 & $\mathrm{~S} 4$ & 87 & 4 \\
M5 & 92 & 5 & $\mathrm{~T} 5$ & 86,5 & 3 & & & \\
& 602 & 38 & & 625,5 & 42 & & 440,5 & 25 \\
& 2 & & & 3 & & & 1 & \\
\hline
\end{tabular}

Source: Author's empirical study result

Well performing enterprises using internal sources of finances including ordinary shares and retained earnings and higher percent of shareholders equity in their capital structures. 


\subsubsection{Hypothesis-3 Conclusion}

Table 19. Existing capital structure varies by type

\begin{tabular}{|c|c|c|c|c|c|c|}
\hline \multirow{3}{*}{$\begin{array}{l}\mathrm{D} / \mathrm{E} \\
\text { ratio } \\
\text { Debt }\end{array}$} & \multicolumn{2}{|c|}{$\begin{array}{l}\text { Manufacturing industry } \\
\text { average }\end{array}$} & \multicolumn{2}{|c|}{ Trading industry average } & \multicolumn{2}{|c|}{ Servicing indus try average } \\
\hline & \multicolumn{2}{|c|}{ Capital Structure } & \multicolumn{2}{|c|}{ Capital Structure } & \multicolumn{2}{|c|}{ Capital Structure } \\
\hline & Average & Median & Average & Median & Average & Median \\
\hline \multirow[t]{3}{*}{ Equity } & 0,60 & 0,63 & 0,66 & 0,64 & 0,37 & 0,28 \\
\hline & 0,56 & 0,56 & 0,67 & 0,66 & 0,45 & 0,28 \\
\hline & 0,44 & 0,44 & 0,33 & 0,34 & 0,55 & 0,72 \\
\hline
\end{tabular}

Source: Author's empirical study result

Based on the above existing capital structures, this paper can approve capital structure varies by industries.

6.1.4 Hypothesis-4 Conclusion

Table 20. Industry average of capital structures

(Limited Liability Company VS public listed company)

\begin{tabular}{lllllll}
\hline & $\begin{array}{l}\text { Manufacturing } \\
\text { companies }\end{array}$ & $\begin{array}{l}\text { Trading } \\
\text { companies }\end{array}$ & $\begin{array}{l}\text { Service } \\
\text { companies }\end{array}$ & $\begin{array}{l}\text { Manufacturing } \\
\text { companies }\end{array}$ & $\begin{array}{l}\text { Trading } \\
\text { companies }\end{array}$ & $\begin{array}{l}\text { Service } \\
\text { companies }\end{array}$ \\
\hline Debt & Limited liability company & & Public listed company & \\
Equity & $56 \%$ & $67 \%$ & $45 \%$ & $74,1 \%$ & $30 \%$ & $16,9 \%$ \\
& $44 \%$ & $33 \%$ & $55 \%$ & $25,9 \%$ & $70 \%$ & $83,1 \%$ \\
\hline
\end{tabular}

Source: Author's empirical study result

In along with the above stated analysis and studies, capital structure varies by type of ownerships. Manufacturing enterprises mainly have higher percentage of debt financing, because of its industry features. Limited liability trading companies mainly using higher percent of debts financings.

\subsubsection{Hypothesis-5 Conclusion}

Based on the result of scenario analysis assumption, optimal capital structure shows by below matrix (minimum WACC and max company value);

Stucture-1: Preferably equity financing

Stucture-2: Debt/Equity proportion is (range between $11 / 89$ and $85 / 15$ ) - WACC is below with expected rate of return

\subsection{Recommendations}

Based on this paper empirical study, here are some recommendations related to the sources of finances and capital structures.

1. All of Mongolian trading, manufacturing and service providing companies use 6 types of sources (mainly external). So, companies need to learn well about sources of finances and how to increase their financial resources'types

2. Cost of equity is getting lower or equal with cost of equity on the Mongolian case.

3. Most selected companies are using short-term sources of finances and companies need to define their long term financial strategy/planning and investments.

4. Majority of selected industries (manufacturing, trading) have higher amount of working capitals and companies need to improve their working capital management efficiency. Because, WCM initiatives release working capital and increase liquidity that can be used for strategic investments or the reduction of debt. In addition, profitability is enhanced due to an efficiency improvement within the processes and a reduction in cost of capital.

5. Selected companies and industries need to define their optimal capital structure based on the existing capital structure. In that case they can increase their value of the company and profits. 


\subsection{Significance of the Results of the Study}

As for the medium enterprises of Mongolia and its stakeholders, this paper will be one of the handbooks that are available to use on their financial sources and capital structuring, in the case of Mongolia, most of medium enterprises shareholders (based on this observation study) usually invest their equity for further business expansion and funding, so especially those shareholders are available to collect information from this paper proposal. On the other hand, as from the financial professional's perspective, this is a very significant paper because the topic is a revised topic at the financial market of Mongolia. In a same time, this paper analysis were based on the actual actively operating limited liability companies' cases on 3 different industries that means its results and analysis are very significant for the financial market of Mongolia.

\section{References}

ACCA. (2009). Paper F9 Financial Management. London: BPP Learning Media Ltd. C.Paramasivan. T. (n.d.). Financial Management. New Delhi: New Ace International P Limited. Center, S. a. (2014). Database for Small and Medium Enterprises. Retrieved December 2015, from http://sme.gov.mn/.

Bradley, M., Jarrell, G. A., \& Kim, E. (1984). On the existence of an optimal capital structure: Theory and evidence. The journal of Finance, 39(3), 857-878. https://doi.org/10.1111/j.1540-6261.1984.tb03680.x

Corporation, I. F. (2014). SMEs and Women-owned SMEs. Washington: International Finance Corporation.

Ganbold, B. (2008). Improving access to finance for SME: international good experiences and lessons for Mongolia. Vol. 438. Institute of Developing Economies.

General Department of Taxation, M. (n.d.). http: www.mta.mn pages 137. https:'1www.lib.uwo.ca, business betasbydatabasebloombergdefmitionojbeta.html. (n.d.). Retrieved from Western Libraries.

Hamisi, S. (2011). Challenges and opportunities of Tanzanian SMEs in adapting supply chain management. African. Journal of Business Management , 5(4), 1266.

Higgins, R. C., \& Reimers, M. (1995). Analysis for financial management (No. s 53). Chicago, IL: Irwin.

Huselid, M. A., Jackson, S. E., \& Schuler, R. S. (1997). Technical and strategic human resources management effectiveness as determinants of firm performance. Academy of Management journal, 40(1), 171-188. https://doi.org/10.2307/257025

Organization for Economic Co-operation and Development. (2005, December 02). https://stats.oecdorg/glossary/detail.asp?ID=3]23. Retrieved December 04, 2001, from The Organization for Economic Co-operation and Development (OECD): OECD, 2005, OECD SME and Entrepreneurship Outlook: 2005, OECD Paris, page 17.

Scott Jr, J. H. (1976). A theory of optimal capital structure. The Bell Journal of Economics, 33-54. https://doi.org/10.2307/3003189

Securities, F. (2015, October 4). Retrieved from 2014 performance of financial sector and banking industry of Mongolia: www.frontier.mn

Stephen, A., \& Ross, R. W. (2013). Fundamentals of Corporate Finance (10th ed., Vol. Standard). NewYork, USA, United States of America: McGraw-Hill/Irwin.

Togtokhbuyan, L. H. X. (2014). Analysis of the returns of small and medium-sized. Journal of Finance and Accounting, 7.

Xiao, W., \& Zhang, J. (2003). On the Bank Credit Rationing and Loan of Small and Medium-Sized Enterprises (SMEs)[J]. Economic Research Journal, 7, 008.

Yifu, L., \&Sun, X. (2005). Information, Informal Finance and SME Financing [J]. Economic Research Journal, 7, 35-44.

\section{Copyrights}

Copyright for this article is retained by the author(s), with first publication rights granted to the journal.

This is an open-access article distributed under the terms and conditions of the Creative Commons Attribution license (http://creativecommons.org/licenses/by/4.0/). 